\title{
Pengembangan Multimedia Pembelajaran Larutan Elektrolit Dan Non Elektrolit Berbasis Multipel Representasi Menggunakan Lectora Inspire
}

\author{
Muhammad Iqbal*, Abdul Hadjranul Fatah, Syarpin \\ Program Studi Pendidikan Kimia, Jurusan Pendidikan MIPA, FKIP, Universitas \\ Palangka Raya, Indonesia \\ Email : Muhammadiqbal303@gmail.com
}

Diterima: 05 Maret 2020; Disetujui: 20 Maret 2020; Diterbitkan: 29 Maret 2020

\begin{abstract}
ABSTRAK
Penelitian ini bertujuan untuk mengetahui isi dan kelayakan multimedia pembelajaran Lectora Inspire berbasis multiple representasi materi Larutan Elektrolit dan Non Elekrolit. Mulimedia pembelajaran ini merupakan perpaduan dari teks, gambar, animasi, dan video. Penelitian pengembangan multimedia pembelajaran berbasis multipel representasi ini menggunakan model Four-D (4D) yang diadaptasi dari Thiagarajan. Penelitian pengembangan ini hanya sampai pada tiga tahap, yaitu define (pendefinisian), design (perancangan) dan develop (pengembangan). Data yang diperlukan pada penelitian ini yaitu data kesesuaian label konsep dengan silabus kurikulum 2013, data kesesuaian konten multimedia pembelajaran menggunakan tabel ceklis label konsep, narasi dan tipologi serta data hasil uji coba produk menggunakan angket respon mahasiswa. Instrumen yang duganakan untuk memperoleh data tersebut adalah tabel identifikasi label konsep dengan silabus kurikulum 2013, tabel identifikasi label konsep, narasi dan tipologi, tabel ceklis kesesuaian label konsep, narasi dan tipologi, serta angket respon. Uji coba produk dilakukan pada mahasiswa kimia angkatan 2018 untuk mengetahui kelayakan mahasiswa terhadap multimedia yang telah dikembangkan. Multimedia pembelajaran berbasis multipel representasi menggunakan lectora inspire terdiri dari halaman beranda, petunjuk penggunaan multimedia, cara membaca navigasi konten serta materi larutan elektrolit dan non elektrolit. Isi konten multimedia pada materi larutan elektrolit dan non elektrolit terdiri dari tujuh label konsep. Rata-rata hasil uji coba produk secara individu sebesar 93,2\%. Sedangkan rata-rata hasil uji coba produk secara kelompok sebesar 93,6\%.
\end{abstract}

Kata Kunci: larutan elektrolit dan non elektrolit, multimedia pembelajaran, multipel representasi.

\section{PENDAHULUAN}

Ilmu kimia mulai dipelajari lebih mendalam pada jenjang pendidikan SMA dan Perguruan Tinggi. Menurut Suyanti (2010) pelajaran kimia dimulai dari konsep-konsep yang sederhana, kemudian dari konsep yang sederhana tersebut dibangun konsep-konsep yang lebih kompleks. Sehingga, dalam mempelajari ilmu kimia tidak jarang ditemukan kesulitan dalam memahami suatu konsepnya. Jika salah satunya saja konsep tersebut tidak dipahami maka akan berpengaruh pada pemahaman untuk konsep-konsep yang lain. Oleh karena itu, untuk menguasai suatu konsep kimia yang kompleks, maka konsep dasar perlu dikuasai. 
Kimia dapat direpresentasikan pada tiga tingkat representasi yang dikenal dengan "Chemistry Triplet" (Talanquer,2011). Tiga representasi ini terdiri dari makroskopik,submikroskopik dan simbolik. Representasi makroskopik merupakan level konkret, dimana pada level ini siswa mengamati fenomena yang terjadi, baik melalui percobaan yang dilakukan atau fenomena yang terjadi pada kehidupan sehari-hari. Representasi submikroskopik merupakan level abstrak yang menjelaskan fenomena makroskopik. Sedangkan representasi simbolik digunakan untuk merepresentasikan fenomena makroskopik dengan menggunakan simbol-simbol kimia, rumus dan persamaan kimia, persamaan matematika, grafik, mekanisme reaksi, serta struktur molekul (Chandrasegaran, et al., 2007)

Larutan elektrolit dan non elektrolit merupakan salah satu materi kimia yang diajarkan disekolah menengah atas dan diajarkan lebih lanjut di perguruan tinggi. Materi larutan elektrolit dan non elektrolit mencangkup konsep abstrak dan konsep berdasarkan prinsip. Materi larutan elektrolit dan non elektrolit mempunyai interkoneksi antara tiga level representasi kimia. Level makroskopik menggambarkan fenomena nyata yaitu nyala lampu pada larutan elektrolit. Level submikroskopik yaitu proses zat terlarut yang menghasilkan adanya arus listrik (Fika, 2017).

Nur aini (2015) hasil penelitian menunjukan bahwa pemahaman konseptual siswa pada materi larutan elektrolit dan non elektrolit sebesar $57 \%$. Lisa (2018) menunjukan bahwa miskonsepsi siswa pada materi larutan elektrolit dan non elektrolit sebesar $54 \%$.

Kesulitan siswa dalam memahami suatu konsep kimia tersebut harus diatasi, Davetak (2013) berpendapat bahwa suatu pembelajaran efektif yang dapat memvisualisasikan dan menjelaskan suatu fenomena sangat diperlukan sehingga siswa mengamati gejala-gejala yang terjadi, mengumpulkan data dan menganalisa serta menarik kesimpulan sehingga diperoleh konsep-konsep yang bersifat bukan hapalan saja, karena pembelajaran tanpa aspek visual tidak dapat terjadi. Pembelajaran tersebut yaitu pembelajaran berorientasi multipel representasi kimia. Untuk memahami kimia yang berdasarkan tiga tingkat representasi yaitu makroskopik, submikroskopik dan simbolik, dibutuhkan pendekatan baru yang mengadaptasikan teknologi dan informasi. Alat-alat teknologi dan informasi salah satunya adalah multimedia pembelajaran.

Lectora Inspire merupakan jenis Authoring Tools (Alat penyusun multimedia) yang efektif dalam membuat multimedia pembelajaran (Mas'ud, 2014). Lectora Inspire memiliki banyak program yang mendukung kebutuhan Full Service Authoring Tools, karena digunakan untuk mengembangkan konten digital materi ajar dan materi uji yang dibentuk menjadi multimedia dinamis, mudah digunakan, dan berkualitas tanpa harus memiliki keahlian desain seni dan desain grafis. Selain itu, memiliki banyak konten seperti animasi, tulisan, gambar, video dan lain-lain. Konten-konten ini dapat mengintregasikan tiga representasi kimia pada satu media pembelajaran. Semua materi kimia dapat dimuat pada multimedia pembelajaran, salah satunya adalah materi reaksi kimia dalam larutan berair.

Rizqiah (2017) hasil penelitan menunjukan bahwa tanggapan peserta didik terhadap kualitas multimedia pembelajaran menggunakan aplikasi lectore inspire sebesar 85,1\% dengan kategori sangat baik. Ardi (2017) menunjukan 
bahwa respon siswa terhadap multimedia interaktif berbasis representasi kimia sebesar 90,49\% dengan kategori sangat baik.

Potensi pengembangan multimedia pembelajaran menggunakan lecora inspire dari uraian diatas, karakteristik materi larutan elektrolit dan non elektrolit, serta penelitian terdahulu tentang pengembangan multimedia pembelajaran dengan hasil respon peserta didik sangat baik. Maka peneliti tertarik untuk melakukan penelitian tentang Pengembangan Multimedia Pembelajaran Larutan Elektrolit dan Non Elektrolit Berbasis Multipel Representasi Menggunakan Lectora Inspire.

Multimedia pembelajaran merupakan kumpulan dari beberapa media seperti tesk, gambar, audio, video, dan animasi yang bersifat interaktif yang digunakan untuk menyampaikan informasi. Ivers \& Ann (2002) menjelaskan "multimedia is the use of several media to present information. Combinations may include text, graphics, animation, pictures, video, and sound". Multimedia adalah penggunaan beberapa media untuk menyajikan informasi. Kombinasi ini dapat berisi teks, grafik, animasi, gambar, video, dan suara. Teknologi saat ini, bagaimanapun memungkinkan pendidik dan siswa untuk menggabungkan dan berinteraksi dengan media pembelajaran dengan mudah. Vaugan (2011) menjelaskan bahwa "Multimedia is any combination of text, art, sound, animation, and video delivered to you by computer or other electronic or digitally manipulated means". Multimedia adalah kombinasi teks, seni, suara, animasi, dan video yang dikirimkan oleh komputer atau sarana elektronik lainnya atau digital dimanipulasi.

Lectora inspire merupakan authoring tool yang digunakan sebagai konten e-Learning yang dikembangkan oleh Trivantis Corporation (Mas'ud 2012). Lectora sangat mudah digunakan dalam mengembangkan konten Multimedia Pembelajaran Interaktif.

Lectora inspire kompatible dengan berbagai system manejemen pembelajaran (Learning Management System). Pada tahun 2000, lectora menjadi AICC bersertifikat pertama authoring system di pasar. Pencapaian ini menunjukkkan kredibilitas lectora sehingga layak mendapatkan penerimaan dalam industri e-learning (Amelia, 2017). Software lectora inspire diciptakan untuk seseorang non programmer dalam mengembangkan konten e-lerning.

Software lectora inspire memiliki banyak keunggulan diantaranya dapat digunakan untuk membuat website, e-Learning interaktif dan presentasi. Isi lectora seperti animasi, gambar, tulisan, grafik, dan video yang mudah digunakan oleh pemula dan dapat dipublikasikan ke berbagai output seperti HTML5, single file Executable (Exe), CDROM, maupun standar e-Learning seperti SCORM dan AICC (Mas'ud, 2012).

Representasi adalah salah satu pondasi praktis ilmiah, karena para ahli menggunakan representasi sebagai cara utama berkomunikasi dan memecahkan masalah (Anwar dkk, 2015). Representasi merupakan penggambaran secara fisik suatu fenomena dan/atau suatu objek yang bersifat abstrak, misalnya isyarat, gambar pada buku teks, dan diagram yang dihasilkan oleh siswa dengan tujuan mengambil benang merah atau poin-poin penting dari sumber pengetahuan tersebut. Representasi melukiskan segala sesuatu, representasi secara eksternal adalah suatu yang terdapat di dunia nyata, baik objek materi, visualisasi, verbal atau bentuk simbol. 
Level makroskopik adalah representasi dari sebagian kejadian nyata dimana dapat diteliti secara sistematis. Contohnya pada gambar 1 diperoleh dari buku Mc Murry et al., (2016:117) menjelaskan tentang nyala lampu pada larutan elektrolit.

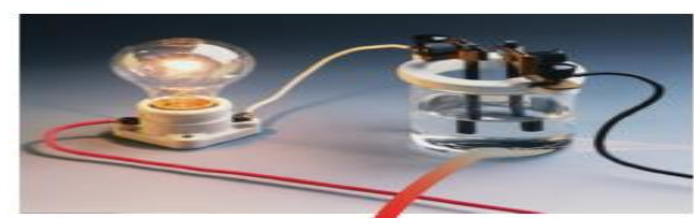

Gambar 1. Representasi Makroskopik

Representasi submikroskopik menyediakan penjelasan pada level partikel dalam bentuk atom, molekul dan ion (Gkitzia et al., 2010:5). Level submikroskopik terdiri dari fenomena kimia yang nyata, yang menunjukkan tingkat partikular sehingga tidak bisa dilihat. Contohnya pada gambar 2 diperoleh dari buku Mc Murry et al., (2016:117) menjelaskan tentang proses terjadinya larutan $\mathrm{NaCl}$ yang dapat menghantarkan arus listrik karena pergerakan pertikel bermuatan (ion), sehingga melengkapi sirkuit dan membuat lampu menyala



Gambar2. Representasi Submikroskopik

Representasi simbolik meliputi penggunaan simbol, rumus dan persamaan, termasuk gambar struktur molekul, diagram, model dan animasi komputer untuk melambangkan suatu materi (Gkitzia, et al., 2010:5). Level simbolik terdiri dari beberapa abstraksi kulitatif yang digunakan untuk menggambarkan setiap materi pada level submikroskopik. Contohnya pada gambar 3 diperoleh dari Mc Murry et al., (2016:117) tentang $\mathrm{NaCl}$ terionisasi ketika dilarutkan didalam air .

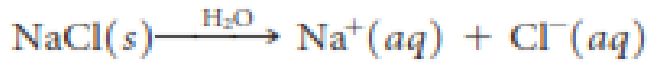

Gambar 3. Representasi Simbolik

\section{METODOLOGI PENELITIAN}

Penelitian ini menggunakan metode penelitian dan pengembangan atau Research and Developmen ( $\mathrm{R} \mathrm{D}$ ). Model yang dipilih dalam penelitian ini menggunakan model 4-D yang dikembangkan oleh Thiagarajan, Semmel, dan Semmel (1974). Model ini terdiri dari 4 tahap pengembangan, yaitu define, design, develop, dan desminate. Pada penelitian ini hanya 3 tahap, yaitu pendefinisian, perencanaan, pengembangan yang diadaptasi dari metode yang digunakan Asi (2017). 
Penelitian ini dilakukan di Program Studi Pendidikan Kimia Universitas Palangka Raya. Objek penelitian ini yaitu mulimedia pembelajaran berbasis multipel representasi menggunakanl lectora inspire pada materi larutan elektrolit dan non elektrolit yang diuji cobakan pada mahasiswa pendidikan kimia angkatan 2018 .

Instrumen penelitian yang digunakan dalam penelitian ini terbagi atas tabel identifikasi kesesuaian label konsep dengan silabus K-13, tabel ceklis label konsep, narasi dan tipologi serta angket respon mahasiswa.

Hasil uji coba produk terbatas yang dilakukan pada mahasiswa angkatan 2018 kemudian dianalisis guna mengetahui kelayakan produk yang diperoleh. Data yang dianalisis pada hasil uji coba produk ini ada dua, yaitu data uji coba produk secara individu dan data uji coba produk secara kelompok. Hasil uji coba produk secara individu sebanyak tujuh belas data. Sedangkan hasil uji coba produk secara kelompok sebanyak empat data. Data tersebut kemudian dihitung rata-rata tiap indikator pertanyaan dengan menggunakan rumus sebagai berikut:

$$
\overline{\mathrm{X}}=\frac{\sum \mathrm{X}}{\mathrm{n}}
$$

$\overline{\mathrm{X}} \quad$ : Skor rata-rata tiap indikator

$\sum x \quad$ : Jumlah skor total setiap indikator

n : Jumlah reviewer

Skor rata-rata tiap indikator telah diperoleh, selanjutnya peneliti menghitung persentase keidealannya menggunakan rumus sebagai berikut:

$\%$ Tiap Aspek $=\frac{\text { Skor } \text { rata-rata tiap aspek }}{\text { Skor tertinggi ideal setiap aspek }} \times 100 \%$

Keterangan :

$\%$ Tiap Aspek = Persentase setiap aspek.

Setelah menghitung persentase tiap aspek, kemudian peneliti menafsirkan kriteria kelayakan multimedia dengan menggunakan tafsiran berdasarkan Arikunto (2008) pada tabel 7 halaman 32

Tabel 7. Tafsiran Persentase

\begin{tabular}{ll}
\hline Persentase & Kriteria \\
\hline $80,1 \%-100 \%$ & Sangat Baik \\
$60,1 \%-80 \%$ & Baik \\
$40,1 \%-60 \%$ & Sedang \\
$20,1 \%-40 \%$ & Rendah \\
$0,0 \%-20 \%$ & Sangat Rendah \\
\hline
\end{tabular}

\section{HASIL PENELITIAN DAN PEMBAHASAN}

Hasil penelitian berupa deskripsi pengembangan produk. Perkembangan dari penelitian ini dimulai dengan deskripsi prototipe produk dan hasil pengembangan. Pembahasan yang diuraikan selajutnya adalah analisis data

\section{Deskripsi Prototipe Produk}

Penelitian dan pengembangan ini menghasilkan produk berupa multimedia pembelajaran (lectora inspire) berbasis multiple representasi materi larutan elektrolit dan non elektrolit. Rekomendasi sistem leptop, notebook atau komputer 
yang dibutuhkan untuk membuka multimedia pembelajaran (lectora inspire) sebagai berikut :

- $\quad$ Sistem Operasi : Windows XP 32/64 bit, Windows 7 32/64 bit, Windows 8.0 32/64 bit, Windows 8.1 32/64 bit, Windows 1064 bit.

- $\quad$ Memori : 1 Gigabyte (GB) ke atas

- $\quad$ Ruang Hard Disk Drive (HDD) : 500 Megabite (MB) ke atas

Deskripsi multimedia pembelajaran yang dikembangkan pada penelitian berbasis multiple representasi materi larutan elektrolit dan non elektrolit adalah sebagai berikut :

\section{Halaman Beranda Multimedia}

Slide halaman beranda multimedia berisi judul multimedia dan beberapa tombol pintas. Tombol pintas tersebut yaitu : tombol pintas menuju petunjuk penggunaan media, tombol pintas menuju slide cara membaca navigasi, tombol pintas menuju peta konsep, dan tombol pintas menuju materi.

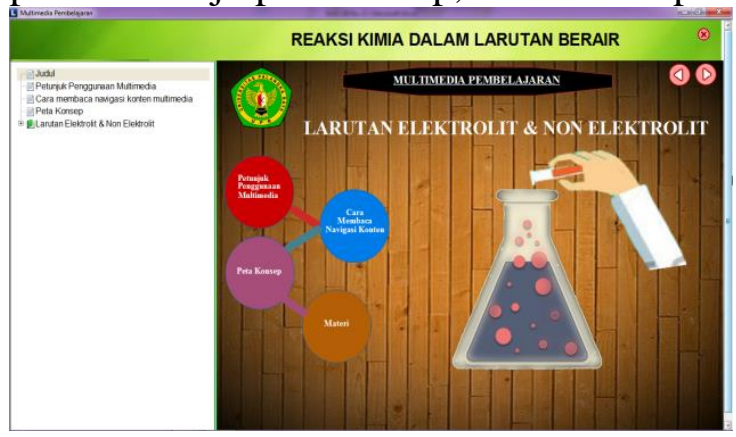

Gambar 4. Beranda Mulimedia

\section{Petunjuk Penggunaan Multimedia Pembelajaran}

Slide petunjuk penggunaan multimedia pembelajaran berisi fungsi dari tombol yang ada pada multimedia pembelajaran. Seperti fungsi dari tombol selanjutnya, kembali, dan keluar.

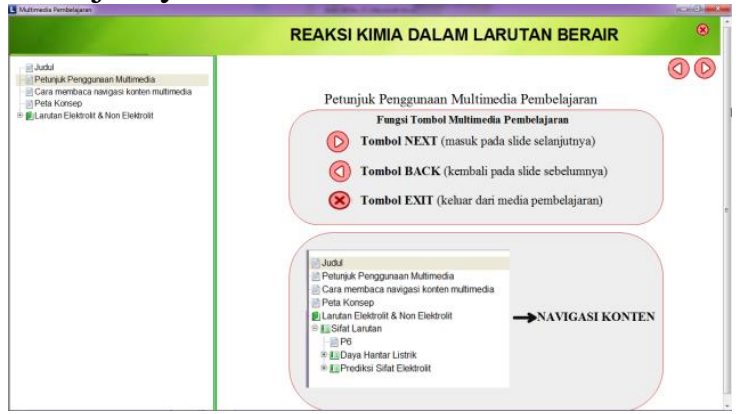

Gambar 5. Petunjuk penggunaan

multimedia pembelajaran

\section{Cara Membaca Navigasi Konten Pembelajaran}

Slide cara membaca navigasi konten pembelajaran berisi petunjuk bagaimana cara membaca sidebar materi pembelajaran. Navigasi konten adalah kedudukan materi pembelajaran pada multimedia yang terletak disebelah kiri. Sedangkan sidebar adalah kolom vertikal yang menampilkan isi dari navigasi konten. Sidebar pada multimedia pembelajaran terletak disebelah kanan. 
Navigasi konten disusun secara sistematis seperti peta konsep, sehingga pemahaman mahasiswa pada materi reaksi kimia dalam larutan air dengan menggunakan multimedia berbasis multiple representasi runtut dan sesuai dengan urutan konsep.

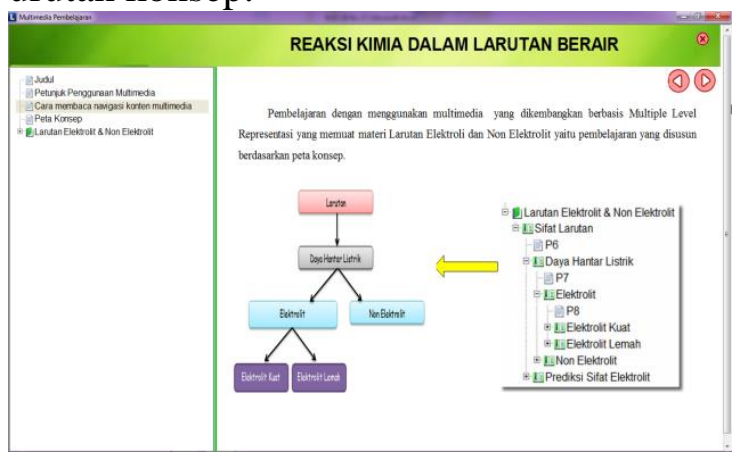

Gambar 6. Cara membaca draft materi pembelajaran

\section{Peta Konsep} elektrolit.

Slide ini berupa peta konsep dari materi larutan elektrolit dan non

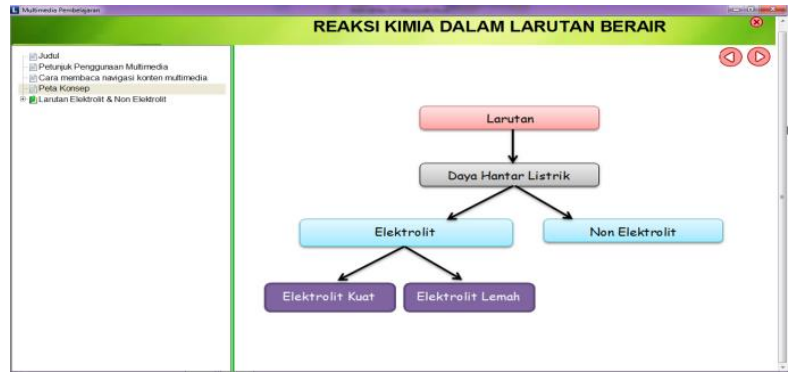

Gambar 7. Peta konsep

Materi

Slide ini berisi materi larutan elektrolit dan non elektrolit. Materi larutan elektrolit dan non elektrolit terdiri dari sifat larutan yaitu daya hantar listrik dan prediksi sifat elektrolit.

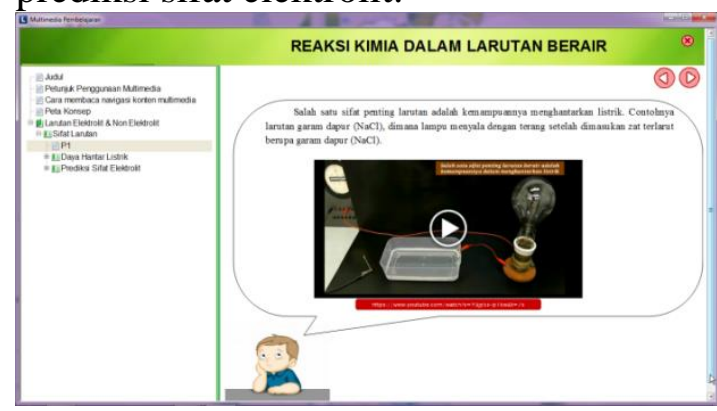

\subsection{Hasil Pengembangan}

Gambar 8. Salah satu slide materi

Produk multimedia pembelajaran berbasis multipel representasi menggunakan lectora inspire pada materi larutan elektrolit dan non elektrolit berisi tujuh label konsep. Label konsep tersebut dicantumkan pada navigasi dan isi materi dicantumkan pada sidebar. Pada tiap slide materi berisi narasi yang merupakan definisi dari label konsep maupun proposisi serta dilengkapi dengan gambar, video, animasi untuk merepresentasikan tipologi makroskopik, 
submikroskopik, dan atau simbolik. Berikut cuplikan screensoot tampilan aplikasi pada tiap slide beserta deskripsinya:

\section{Tampilan Materi Slide Empat}

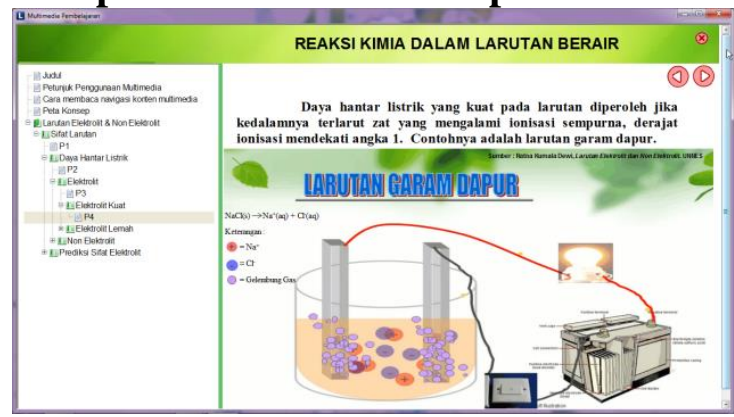

Gambar 12. Tampilan Materi Slide Empat

Tampilan materi slide empat pada gambar 12 halaman 43 berisi narasi tentang larutan elektrolit kuat. Selain itu, slide tersebut dilengkapi dengan animasi uji daya hantar larutan elektrolit kuat. Animasi tersebut berformat Graphics Interchange Format $(G I F)$ sehingga pergerakan animasi terbatas dan berulangulang. Animasi tersebut merepresentasikan ketiga tipologi, yaitu tipologi makroskopik, tipologi submikroskopik dan tipologi simbolik. Tipologi makroskopik mengambarkan lampu yang menyala terang dan adanya gelembung gas. Tipologi Submikroskopik menggambarkan pergerakan ion-ion zat terlarut. Tipologi simbolik menggambarkan rumus atau persamaan zat terlarut menjadi ion-ion.

\section{Deskripsi Analisis Data Uji Coba Produk Secara Individu}

Analisis data yang diperoleh dari hasil uji coba produk terbatas yaitu simulasi berupa angket respon mahasiswa yang meliputi lima aspek. Adapun lima aspek tersebut adalah aspek tampilan, aspek kualitas isi, aspek ke praktisan, aspek tata bahasa dan aspek motivasi. Grafik kelayakan multimedia pembelajaran berbasis multiple representasi pada materi reaksi kimia dalam larutan berair, dapat dilihat pada gambar 19.

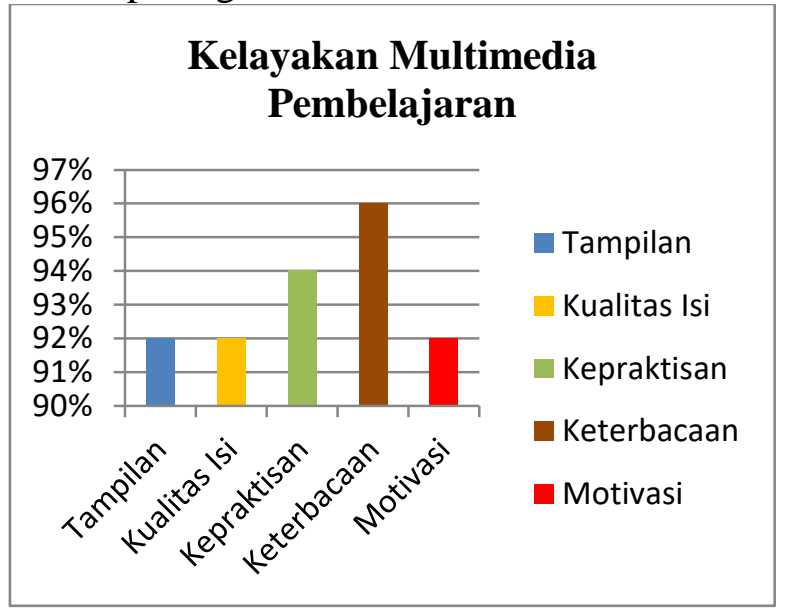

Gambar 19. Grafik Kelayakan Multimedia Pembelajaran Secara Individu

Grafik kualitas multimedia pembelajaran dapat dilihat bahwa aspek tampilan memiliki nilai persentase sama dengan aspek kualitas isi dan aspek 
motivasi, yaitu dengan persentase 92\% . Sehingga dapat disimpulkan bahwa tanggapan mahasiswa terhadap tampilan multimedia pembelajaran sangat baik (SB). Tampilan multimedia pembelajaran secara umum terdiri dari navigasi konten dan sidebar, sehingga pada saat simulasi mahasiswa beranggapan konsep aplikasi multimedia pembelajaran berbasis multipe representasi tergolong baru dan menarik.

Aspek kualitas memiliki nilai persentase sebesar 92\%. Dilihat dari grafik pada aspek kualitas isi dapat disimpulkan bahwa tanggapan mahasiswa terhadap kualitas isi sangat baik. Aspek kualitas isi terdiri dari video, animasi, gambar serta penjelasan materi. Mahasiswa yang bernama teguh kurniawan beranggapan bahwa alangkah baiknya lagi jika dalam aplikasi lebih banyak lagi memuat video,gambar serta animasi.

Aspek kepraktisan memiliki nilai persentase terbesar kedua setelah aspek keterbacaan. Aspek kepraktisan memiliki nilai persentase sebesar 94\% kategori sangat baik. Sehingga dapat disimpulkan bahwa multimedia pembelajaran berbasis multipel representasi pada materi reaksi kimia dalam larutan berair mudah digunakan.

Aspek keterbacaan jika dilihat dari grafik memiliki nilai persentase paling besar jika dibandingkan dengan aspek yang lainnya yaitu sebesar $96 \%$ tergolong kategori sangat baik. Sehingga dapat disimpulkan bahwa dari segi keterbacaan isi multimedia sudah jelas, bahasa yang digunakan benar dan mudah dipahami.

Aspek motivasi jika dilihat dari grafik memiliki nilai persentase sebesar 92\% tergolong kategori sangat baik. Sehingga dapat disimpulkan bahwa pada multimedia pembelajaran berbasis multipel representasi dapat membantu meningkatkan motivasi belajar.

\section{Deskripsi Analisis Data Uji Coba Produk Secara Kelompok}

Analisis data uji coba produk secara kelompok diperoleh dari hasil uji coba produk terbatas yaitu simulasi produk secara berkelompok. Pada saat simulasi produk, kelompok di bagi menjadi empat. Tiap-tiap kelompok terdiri dari empat orang. Masing-masing kelompok menilai kelayakan mulimedia pembelajaran berbasis multiple representasi pada materi reaksi kimia dalam larutan berair. Grafik kelayakan multimedia pembelajaran secara berkelompok, dapat dilihat pada gambar 20 .

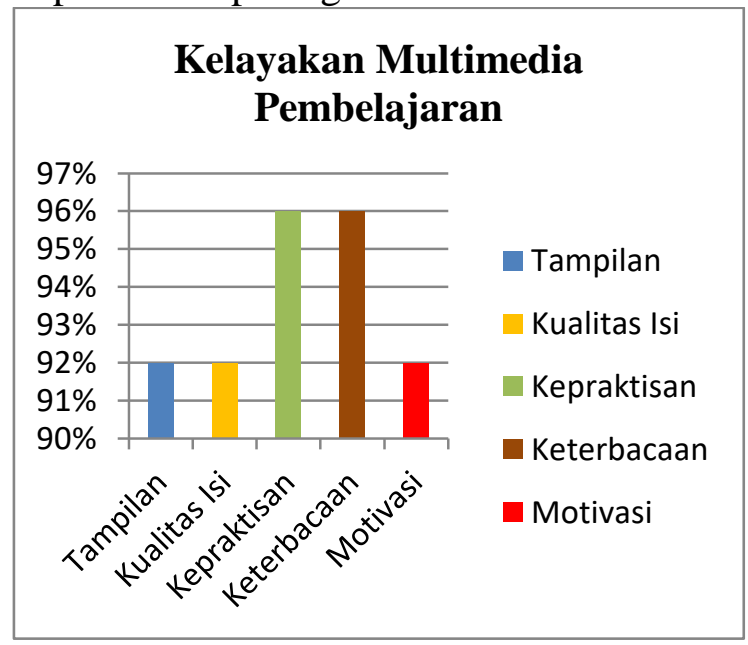

Gambar 20. Grafik Kelayakan Multimedia Pembelajaran Berkelompok 
Grafik kualitas multimedia pembelajaran dapat dilihat bahwa aspek kepraktisan dan aspek keterbacaan memiliki nilai persentase tertinggi dibandingkan aspek yang lainnya yaitu sebesar 96\% dengan kategori sangat baik. Aspek tampilan, aspek kualitas isi dan aspek motivasi memiliki nilai persentase yang sama yaitu sebesar $92 \%$ dengan kategori sangat baik.

\section{SIMPULAN}

Isi multimedia pembelajaran menggunakan lectora inspire berbasis multiple representasi meliputi halaman beranda multimedia, petunjuk penggunaan multimedia pembelajaran, cara membaca navigasi konten pembelajaran, peta konsep dan materi. Materi yang dimaksud yaitu larutan elektrolit dan non elektrolit. Kelayakan multimedia pembelajaran berdasarkan hasil uji coba produk terbatas berupa simulasi produk secara individu yaitu tergolong sangat baik dengan persentase rata-rata 93,2\%. Dari aspek tampilan dengan persentase $92 \%$ tergolong kategori Sangat Baik (SB). Aspek kualitas isi dengan persentase 92\% tergolong kategori Sangat Baik (SB). Aspek kepraktisan dengan presentasi 94\% kategori Sangat Baik (SB). Aspek keterbacaan dengan persentase $96 \%$ kategori Sangat Baik (SB). Aspek motivasi dengan persentase 92\% kategori Sangat Baik (SB). Kelayakan multimedia pembelajaran berdasarkan hasil uji coba produk terbatas berupa simulasi produk secara berkelompok yaitu tergolong sangat baik dengan persentase rata-rata 93,6\%. Dari aspek tampilan dengan persentase $92 \%$ tergolong kategori Sangat Baik (SB). Aspek kualitas isi dengan persentase 92\% tergolong kategori Sangat Baik (SB). Aspek kepraktisan dengan presentasi $96 \%$ kategori Sangat Baik (SB). Aspek keterbacaan dengan persentase 96\% kategori Sangat Baik (SB). Aspek motivasi dengan persentase 92\% kategori Sangat Baik (SB).

\section{DAFTAR PUSTAKA}

Arikunto, S. 2008. Evaluasi Program Pendidikan. Jakarta: Bumi Aksara.

Anwar, Khairul., Sunyono, Nina Kadaritna. 2015. Pembelajaran Model Simayang Tipe II untuk Meningkatkan Model Mental dan Penguasaan Konsep. FKIP: Universitas Lampung.

Ardi, Ahmad Maulana. 2017. Pengembangan Multimedia Interaktif Berbasis Representasi Kimia Pada Materi Laju Reaksi untuk Siswa Kelas XI SMAN 4 Kota Jambi. Universitas Jambi.

Amelia, Hanny. 2017. Pengembangan Multimedia Pembelajaran Menggunakan Lectora Inspire Pada Materi Ruang Lingkup Kimia Untuk Siswa Kelas X di SMAN 4 Kota Jambi. Universitas Jambi.

Asi, N.B. 2017. Pengembangan Bahan Ajar Kimia Bahan Makanan Berbasis Web. Jurnal Ilmiah Kanderang Tingang. 8, 2 (Des. 2017), 163-170.

Chandrasegaran, L.A., Treaagust, D., \& Mocerino, M. 2007. The development of a two-tier multiple-choice diagnostic instrument for evaluating secondary 
school student explain chemical reaction using multiple level of representation. Chemistry Education Research and Practice, 8 (3), hlm. 293-307

Dahar, R. W. 2011. Teori-Teori Belajar dan Pembelajaran. Jakarta: Erlangga.

Davetak. 2013. Teachers Influence Students Motivation for Learning Science with Understanding. Eurasia Journal of Mathematics, Science \& Technology Education

Fika, Rakhmalinda. 2017. Identifikasi Model Mental Berdasarkan Tiga Level Representasi Pada Materi Larutan Elektrolit dan Non Elektrolit. Universitas Islan Negeri Syarif Hidayatullah.

Gkitzia, V., Salta, K, dan Tzougraki, C. 2010. "Development and Application of Suitable Criteria for the Evaluation of Chemical Representations in School Textbooks", Chemistry Education Research and Practice, 12, 5-14.

Gilbert, et al. 2008. Visualization: Theory and Practice in Science Education. Australia: Springer

Herron, J. Dudley., et. al. 1977. Problems Associated With Concept Analysis. Journal of Science Education, (61)2: 185 - 199.

Hariyanto, Suyono. 2011. Belajar dan Pembelajaran. Bandung: Remaja Rosdakarya

Ivers, K. S. \& Ann E. B. 2002. Multimedia projects in education : designing, producing, and assessing. Second Edition. California : LIBRARIES UNLIMITED Teacher Ideas Press.

Lisa, Putri. 2018. Idenifikasi Miskonsepsi Siswa pada Materi Larutan Elektrolit dan Non Elektrolit di SMAN-4 Banda Aceh. Umiversitas Islam Negeri ArRanry Darusalam Bnada Aceh.

Munir. 2012. Multimedia konsep dan aplikasi dalam pendidikan. Bandung: Alfabeta.

Mas'ud, Muhammad. 2014. Membuat Multimedia Pembelajaran dengan Lectora. Yogyakarta: Pustaka Shonif.

Mc Murry, John E. dan Fay, R obert C. 2016. Chemistry. (Ed. Seven).

Nur'aini, W. 2015. Analisis Pemahaman Konseptual Materi Larutan Elektroli dan Non Elektrolit Kelas X IPA SMAN 9 Malang. FKIP:Universitas Negeri Malang 
Peraturan Pemerintah Republik Indonesia . 2005. Peraturan Pemerintah Republik Indonesia Nomor 19 Tahun 2005 tentang Standar Nasional Pendidikan. Jakarta : Depdiknas.

Rizqiyah, P. 2017. Pengembangan Multimedia Pembelajaran (Lectora Inspire) Berbasis Multiple Level Representasi Materi Kelarutan dan Hasil Kali Kelarutan. UIN Walisongo Semarang.

Setyosari, Punaji. 2012. Metode Penelitian Pendidikan dan Pengembangan. Kencana Prenada Jakarta : Media Group.

Suyanti, R.D. 2010. Strategi Pembelajaran Kimia. Yogyakarta: Graha Ilmu.

Sugiono. 2008. Metode Penelitian Pendidikan. Bandung: Alabeta.

Sudjana, N. 2005. Metode Statistika Edisi Keenam. PT Tarsito: Bandung.

Thalanquer, V. 2011. Macro, Submicro and Simbolic: The many faces of the chemistry "triplet”. International Journal of Science Education. 33 (2). 179-195.

Thiagarajan, S., Semmel, D. S., and Semmel, M. I. 1974. Instruktional Development for Training Teachers of Exceptional Children. A Sourcebook. Indiana: Indiana University.

Vaugan, T. 2011. Multimedia: making it work. Eighth Edition. New York: Technology Education Mac Graw Hill.

Widyoko, Eko Putro. 2012. Tekhnik Penyusunan Instrumen. Yogyakarta: Pustaka Pelajar.

Wiratmojo P dan Sasonohardjo.2002. Media Pembelajaran Bahan Ajar Diklat Kewidyaiswaraan Berjengjang Tingkat Pertamaa. Lembaga Administrasi Negara

Wu Hsin-kai, S Krajick and Solloway Eliot. 2000. Promoting Conceptual Understanding of Chemical Representation: Students Use of a Visualization Tool in Classroom. Paper. University of Michigan. 